\title{
Causes and Consequences of Host Expansion by Mnesampela privata
}

\author{
Fredrik Östrand • Ian R. Wallis • Noel W. Davies • \\ Mamoru Matsuki • Martin J. Steinbauer
}

Received: 24 September 2007 /Revised: 3 December 2007 / Accepted: 13 December 2007 / Published online: 23 January 2008

(C) Springer Science + Business Media, LLC 2007

\begin{abstract}
The autumn gum moth, Mnesampela privata, utilizes several species of Eucalyptus planted outside regions of endemism within Australia. We investigated whether foliar monoterpene composition influenced oviposition in the field on the natural primary host $(E$. globulus) and a novel host (E. rubida), both characterized by nonstructural epicuticular waxes. In the laboratory, oviposition preferences of females for species and families of known host, novel hosts, and non-hosts that were characterized by both nonstructural and structural waxes but also varied in foliar concentrations of the purportedly toxic plant secondary metabolite (sideroxylonal) were
\end{abstract}

Electronic supplementary material The online version of this article (doi:10.1007/s10886-007-9422-y) contains supplementary material, which is available to authorized users.

F. Östrand

Chemical Ecology and Ecotoxicology, Department of Ecology,

Lund University,

SE-223 62 Lund, Sweden

\section{R. Wallis}

School of Botany and Zoology,

The Australian National University,

Canberra A.C.T. 0200, Australia

\section{N. W. Davies}

Central Science Laboratory, University of Tasmania,

Private Bag 74, Hobart, Tasmania 7001, Australia

\section{Matsuki}

Co-operative Research Centre (CRC) for Sustainable

Production Forestry and University of Tasmania,

c/- Department of Agriculture-Western Australia,

444 Albany Highway,

Albany, WA 6330, Australia studied. Although M. privata laid as many eggs on trees of two families of E. rubida as they did on trees of two families of $E$. globulus, there were significant differences in the numbers of clutches of eggs laid. When combined with data for oviposition on another five families of $E$. globulus, we found a negative relationship between mean numbers of eggs and foliar concentration of $\alpha$-pinene but a positive relationship between egg numbers and the concentration of $\alpha$-terpineol. The field data suggest that female $M$. privata are just as willing to lay eggs on novel hosts with comparable foliar monoterpene compositions to those of the primary host, especially if they produce

M. J. Steinbauer

CRC for Sustainable Production Forestry

and CSIRO Entomology,

GPO Box 1700, Canberra A.C.T. 2601, Australia

Present address:

F. Östrand

Ministervägen 4,

SE-227 62 Lund, Sweden

Present address:

M. Matsuki

Bluegum Industry Pest Management Group, CRC for Forestry and Murdoch University, Department of Agriculture and Food

Western Australia,

444 Albany Highway,

Albany, WA 6330, Australia

Present address:

M. J. Steinbauer $(\square)$

Australian Plague Locust Commission,

GPO Box 858, Canberra A.C.T. 2601, Australia

e-mail: martin.steinbauer@daff.gov.au 
nonstructural epicuticular waxes. Oviposition assays in the laboratory endorse this mechanism of host plant hierarchy and support the long-held assumption of the host primacy of E. globulus. In laboratory assays, some larvae pupated on all hosts (except Corymbia eximia) but the number completing larval development was greater on hosts with softer leaves. Larval survival was also reduced on hosts with high concentrations of sideroxylonal but only if those hosts also had modest to high concentrations of monoterpenes. Larval survival was high on a host (E. macarthurii) with a high concentration of sideroxylonal but with virtually zero monoterpene content. This suggests that the monoterpene content of a host could antagonize the effect on $M$. privata larvae of its sideroxylonal content. The larval food plant most affected the fitness of female rather than male pupae. Of the known host expansion events, all have occurred in mixed species plantations. The co-occurrence in these plantations of either the primary host or other highly ranked species probably explains the eventual expansion onto the neighboring species of Eucalyptus and Corymbia.

Keywords Myrtaceae · Autumn gum moth - Geometridae . Antagonistic chemical interactions · Exaptation .

Oviposition mistakes $\cdot$ Lepidoptera

\section{Introduction}

The evolution of insect host specificity and host plant hierarchies depends on the suite of plant and insect species that coincided at a particular time and place (Janz and Nylin 1998; Janz et al. 2001; Braby and Trueman 2006). Typically, insect herbivores expand onto novel plant species that are taxonomically related and/or possess similar suites of plant secondary metabolites (PSMs). For example, the native Brazilian geometrid, Thyrinteina arnorbia, now exploits eucalypts (Grosman et al. 2005), whereas its natural hosts were a suite of endemic Myrtaceae. Hence, the expansion of T. arnorbia onto Eucalyptus provides an example of a host shift between related plant species. Perhaps rarer are instances when insects use unrelated plant families that possess similar PSMs to those of their natural hosts. Murphy and Feeny (2006) found that chemically similar extracts from both the ancestral host (family Apiaceae) as well as from three novel hosts (family Asteraceae) stimulated oviposition in two species of butterfly that belong to the Papilio machaon group. Steinbauer and Wanjura (2002) observed normally eucalypt-feeding species of Anoplognathus (Coleoptera: Scarabaeidae) eating the leaves of Schinus molle (family
Anacardiaceae) and suggested that they were attracted by a similar monoterpene signal.

Mnesampela privata (Guenée) (Lepidoptera: Geometridae, Ennominae) is endemic to forests in south-eastern and south-western Australia. Before being called the "autumn gum moth," it was the "blue gum moth" because the only larval host then known was juvenile blue gum, Eucalyptus globulus (French 1900; Froggatt 1923; Evans 1943). Studies with E. globulus by Steinbauer (2002) and Steinbauer et al. (2004) revealed that females prefer to oviposit on the waxiest types (i.e., juvenile) and sides of leaves. The advent of plantation forestry has led to a reappraisal of the host status of Eucalyptus species that $M$. privata uses. One of the first cases of host expansion involved shining gum (Eucalyptus nitens), soon after its introduction to Tasmania (D. W. de Little, unpubl.). Other plantation and amenity eucalypts that $M$. privata now uses include E. botryoides, E. camaldulensis, E. grandis, E. macarthurii, E. rubida, E. viminalis, and Corymbia maculata (see Steinbauer and Matsuki 2004, and references cited therein). One expansion, onto E. grandis, in northwestern Victoria, is particularly interesting because earlier records of $M$. privata that use this eucalypt are only from regions where the tree was endemic (Moore 1972). Less surprising are infestations of plantation E. globulus in southwest Western Australia (Loch and Floyd 2001; Hobbs et al. 2003), where E. globulus is far from its endemic region (Tasmania and south-eastern Australia). Because expansion and utilization of novel hosts by $M$. privata is not always documented, the phenomenon has seemed random and inexplicable to some. For example, M. privata had little effect on E. macarthurii in two mixed species plantations (Roberts and Sawtell 1981; Stone and Urquhart 1992), but it completely defoliated the species in another (E. G. Neumann and N. G. Collett, unpubl.). The events mentioned above show that this insect has successfully utilized species of eucalypt that either did not occur in a given region or were scarce in that location before plantations.

Eucalypt taxonomy is in a state of flux. In this work, the classification of Chippendale (1988) is followed, although Brooker (2000) proposes a more recent classification (but see Ladiges and Udovicic 2000). Much of the debate revolves around the status of Corymbia-whether it is a subgenus of Eucalyptus or has full genus status (Hill and Johnson 1995; Ladiges et al. 1995; Udovicic et al. 1995). Regardless of classification, Corymbia is still a taxon somewhat removed from the subgenera Monocalyptus and Symphyomyrtus, which explains our reason for studying it. None of the aforementioned authors disputes the subgeneric status of Monocalyptus or Symphyomyrtus. We know of no 
published work that collates patterns of host tree utilization by native insects based on eucalypt PSMs.

The genus Eucalyptus provides an ideal group in which to study host shifts. Although there are more than 900 species, they rarely form single species forests of more than a few hectares and usually grow in close association with individuals of two, three, or more other species (WardellJohnson et al. 1997). Furthermore, different species of Eucalyptus, especially those belonging to the same subgenera, share many foliar PSMs, notably epicuticular waxes, monoterpenes, and formylated phloroglucinol compounds (FPCs; Boland et al. 1991; Li et al. 1995, 1996, 1997; Eschler et al. 2000). Hence, native eucalypt-eating insects are commonly exposed to a mosaic of volatile stimuli. Because the antennae of female $M$. privata respond to a number of ubiquitous eucalypt monoterpenes, Steinbauer et al. (2004) suggested that they are used as host location and assessment cues. These authors have also shown that the odors of the epicuticular waxes of new leaves stimulate the antennae of female moths more than do the odors of waxes from old leaves or the wax odors of glossy leaves. Steinbauer et al. (2004) have suggested that waxes provide host assessment/acceptance cues for female $M$. privata. When female $M$. privata mistakenly oviposit on E. melliodora or E. sideroxylon (both of which produce waxy leaves), their larvae suffer high neonate mortality. Steinbauer and Matsuki (2004) suggested that high neonate mortality on trees of these two species was because of high concentrations of sideroxylonal. Sideroxylonal is an FPC common to Symphyomyrtus species but present in some in much higher concentrations than in others. If it is possible to explain past host expansion events and oviposition mistakes by $M$. privata, then it may be possible to foresee future events.

\section{Methods and Materials}

Field Investigations of Oviposition Preferences for Novel and Natural Hosts The field investigations were conducted

Table 1 The eucalypts studied, their host utilization by Mnesampela privata and the characteristics of their epicuticular waxes

\begin{tabular}{|c|c|c|c|}
\hline Species & $\begin{array}{l}\text { Family Name and } \\
\text { Code }\end{array}$ & $\begin{array}{l}\text { Host Status and Wax Type (latter from Hallam } \\
\text { and Chambers 1970) }\end{array}$ & $\begin{array}{l}\text { Ontogeny and Distribution of } \\
\text { Waxes }\end{array}$ \\
\hline \multicolumn{4}{|c|}{ Field investigations GES2 } \\
\hline E. rubida & Boboyan Forest R28 & $\begin{array}{l}\text { Novel host; nonstructural waxes } \\
\text { (tubes, compound, branching acutely) }\end{array}$ & $\begin{array}{l}\text { Juvenile leaves waxiest; isobilaterally } \\
\text { waxy }\end{array}$ \\
\hline E. rubida & Glendale Crossing R22 & As above & As above \\
\hline E. globulus & Otways Nat. Park G25 & $\begin{array}{l}\text { Natural host; nonstructural waxes (tubes, } \\
\text { compound, branching acutely) }\end{array}$ & $\begin{array}{l}\text { Juvenile leaves waxiest; abaxial very } \\
\text { waxy, adaxial less waxy }\end{array}$ \\
\hline E. globulus & Jeeralang North G19 & As above & As above \\
\hline \multicolumn{4}{|c|}{ Field investigations GES1 } \\
\hline E. globulus & Geeveston G76 & See details for $\mathrm{G} 25$ & See details for $\mathrm{G} 25$ \\
\hline E. globulus & Otways Nat. Park G25 & As above & As above \\
\hline E. globulus & Jeeralang North G19 & As above & As above \\
\hline E. globulus & Badgers Creek G10 & As above & As above \\
\hline E. globulus & King Island G8 & As above & As above \\
\hline \multicolumn{4}{|c|}{ Laboratory investigations } \\
\hline E. globulus & Geeveston G76 & See details for $\mathrm{G} 25$ & See details for $\mathrm{G} 25$ \\
\hline E. nitens $\left(4^{\mathrm{a}}\right)$ & Toorongo N63 & $\begin{array}{l}\text { Novel host; nonstructural waxes (tubes, } \\
\text { compound, branching acutely) }\end{array}$ & $\begin{array}{l}\text { Juvenile leaves waxiest; isobilaterally } \\
\text { waxy }\end{array}$ \\
\hline E. nitens $\left(3^{\mathrm{a}}\right)$ & Southern N.S.W. N64 & As above & As above \\
\hline E. nitens $\left(2^{\mathrm{a}}\right)$ & Macalister N65 & As above & As above \\
\hline E. nitens $\left(1^{\mathrm{a}}\right)$ & Rubicon N66 & As above & As above \\
\hline Corymbia eximia & Black Mountain Cor & Unknown status; structural waxes ${ }^{\mathrm{b}}$ & $\begin{array}{l}\text { Leaf types comparable; isobilaterally } \\
\text { dull matt }\end{array}$ \\
\hline E. macarthurii & Black Mountain Mac & Unknown status; structural waxes ${ }^{\mathrm{b}}$ & $\begin{array}{l}\text { Juvenile leaves waxiest; abaxial dull matt, } \\
\text { adaxial sub-glossy }\end{array}$ \\
\hline
\end{tabular}

${ }^{\text {a }}$ Visual ranking of waxiness where $1=$ most waxy and $4=$ least waxy

${ }^{\mathrm{b}}$ Waxes not studied by Hallam and Chambers (1970). 

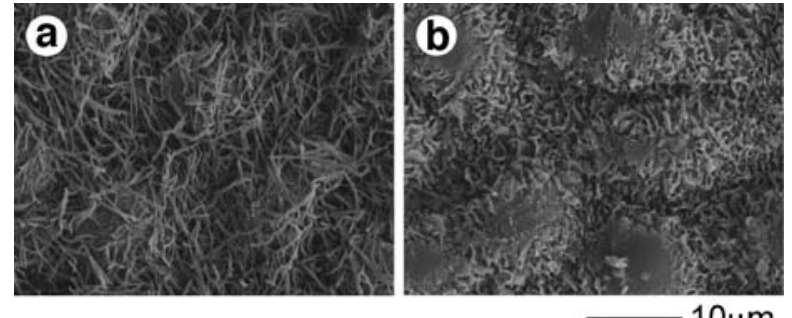

Fig. 1 Scanning electron micrographs of the epicuticular waxes of two hosts used in the laboratory investigations. a Abaxial surface of leaf of E. nitens family N66 showing nonstructural waxes and $\mathbf{b}$ leaf of $C$. eximia showing structural waxes. Nonstructural waxes can be removed by abrasion, whereas structural waxes cannot

in two common arboreta, i.e., Ginninderra Experiment Stations 2 and 1, hereafter referred to as GES2 and GES1. Our objective was to compare the oviposition preferences of $M$. privata for trees belonging to five families of $E$. globulus with those for two families of E. rubida (a novel host). Both species have waxy leaves, the chemical composition of which relates them to other species that possess nonstructural waxes (Table 1. Fig. 1). Because of their close taxonomic affinity (both subgenus Symphyomyrtus, series Viminales), it was thought that differences in oviposition according to species and family would indicate the influence of foliar monoterpenes on female preference. We surveyed 54 trees of each species in GES2 and 100 of each in GES1 for egg clutches for $1 \mathrm{~min}$ on at least 11 separate occasions that spanned two moth seasons. At the end of a survey, the numbers of eggs in each previously located clutch was counted. Data are expressed as the mean number of clutches or eggs per target tree per minute per survey.
Our interest was the influence of tree genotype on oviposition rather than the timescale of oviposition, so we ignored the repeated measures aspect of the data. Observations of "nil oviposition" were also ignored, which caused the oviposition data to be unbalanced. Therefore, general linear modeling (GLM) using the data for clutches and square root transformed egg data were used to assess oviposition preferences according to species and families of trees. The number of leaves examined during each 1-min survey and the number of clutches found were included as covariates, but were dropped from later models if statistically insignificant. A post hoc one-way analysis of variance (ANOVA) of transformed data was used to compare individual means.

Laboratory Investigations of Oviposition Preferences for Novel and Natural Hosts The attractiveness of natural and novel hosts was compared by using binary choice assays with groups of females and also by using multiple choice assays with individual females (details given in Table 2). With the exception of $C$. eximia, the two novel host species (E. nitens and E. macarthurii) belong to the subgenus Symphyomyrtus (series Viminales). Furthermore, the four E. nitens showed considerable variation in the waxiness of their leaves, all of which have nonstructural waxes, whereas $C$. eximia and $E$. macarthurii have structural epicuticular waxes that cannot be abraded. Eucalyptus globulus had waxier leaves than the waxiest $E$. nitens studied. The foliage of the four E. nitens came from another common arboretum, i.e., GES3. Of the other two trees, leaves of $C$. eximia were taken from a specimen growing in the grounds of Commonwealth Scientific and Industrial Research Organisation, whereas leaves of E. globulus came from a specimen growing in the garden of MJS (specimen belonged to same family as that planted in GES1).

Table 2 Laboratory investigations used to assay responses of Mnesampela privata to novel and natural hosts as well as hosts of unknown host status $(\mathrm{F}=$ female and $\mathrm{M}=$ male $)$

\begin{tabular}{llll}
\hline Assay & $\begin{array}{l}\text { Branchlets (moths) and } \\
\text { Leaves (larvae) Per Assay }\end{array}$ & $\begin{array}{l}\text { Number of Insects } \\
\text { Per Assay }\end{array}$ & $\begin{array}{l}\text { Number of Cages (moths) or Dishes } \\
\text { (larvae) Per Assay }\end{array}$ \\
\hline $\begin{array}{l}\text { Oviposition preference } \\
\text { Binary choice }\end{array}$ & $\mathrm{N} 66, \mathrm{G} 76$ & $3-4 \mathrm{f}, 3-6 \mathrm{~m}$ & 9 \\
As above & $\mathrm{N} 64, \mathrm{~N} 66$ & $4 \mathrm{f}, 4-5 \mathrm{~m}$ & 7 \\
As above & Mac, N64 & $4 \mathrm{f}, 3-5 \mathrm{~m}$ & 5 \\
As above & Cor, N64 & $4 \mathrm{f}, 3 \mathrm{~m}$ & 5 \\
As above & N64, N66 & $1 \mathrm{f}, 1-3 \mathrm{~m}$ & 11 \\
Multiple choice & N63, N64, N65, N66 & $1 \mathrm{f}, 1-3 \mathrm{~m}$ & 13 \\
Larval survival and performance & & 6 per tree \\
& Cor, Mac, N66, G76 & 5 eggs per leaf & 6 per tree \\
\hline
\end{tabular}


To ensure that test females were host novices, male and female pupae were allowed to ecdyse in the cages that housed the test foliage. Assays were conducted in cages $(54 \times 37 \times 28 \mathrm{~cm})$ with gauze sides housed in a controlled temperature room (range $20-21^{\circ} \mathrm{C}$ ) under a $12: 12 \mathrm{~h}$ reverse-cycle lighting regimen with a fan circulating air. Branchlets were pruned so that they had either the same number of leaves or about the same leaf area before placing them upright in containers of moistened floral foam in diagonally opposite corners of cages. Moths were given 5\% sugar water for sustenance. Branchlets were left for 7 days before removing them, counting the eggs, and measuring the total leaf area (i.e., leaf area multiplied by 2), with an AM100 portable leaf area meter (ADC Bioscientific Ltd., Herts).

Two-tailed paired-sample $t$-tests were used to analyze the results from binary choice assays after first transforming the data - square root (eggs +0.5 ) - to account for zero values. Paired $t$-tests cannot incorporate covariates, such as leaf area, and so these were compared separately. There were significant differences in total leaf area per cage only for $E$. macarthurii vs. E. nitens N64 $(P=0.001)$. The juvenile leaves of $E$. macarthurii were a third the size of those of $E$. nitens N64, so it was difficult to match leaf area per cage. Nevertheless, the preference of females for E. nitens N64 over E. macarthurii could be because of differences in the leaf areas.

A GLM was used to analyze the results of the multiple choice assays, with leaf area as a covariate, after transforming the data [square root $($ eggs +0.5$)]$. The total leaf area did not explain significant variation $(P=0.57)$ and was dropped from later models. A post hoc one-way ANOVA of the transformed data was used to separate the treatment means.

Laboratory Investigations of Larval Survival and Performance on Novel and Natural Hosts In two sets of assays, the survival and performance of larvae, from hatching to pupation, was assayed by using leaves of all the trees used in the oviposition experiments. In the first set of assays, the survival of six groups of five larvae on each of $E$. globulus, E. nitens N66, E. macarthurii, and C. eximia was followed by recording the number of dead larvae twice weekly. The second set of assays was the same, except larvae were reared on leaves of the four E. nitens. Groups of larvae were reared in individual $15-\mathrm{cm}$ Petri dishes (same temperature and lighting regime as used for the oviposition assays) with saturated plaster of Paris bases until the third instar and then transferred them to 750-ml plastic containers each half filled with moist vermiculite as a pupation substrate. Fresh leaves were supplied to all groups of larvae at the same time when needed. Individuals that pupated were sexed, oven dried at $40^{\circ} \mathrm{C}$, and weighed.

Log-rank tests were used to compare pairs of KaplanMeier survival curves. Because there were six pairs of comparisons per survival assay, the test statistic was compared against critical values of the chi-square distribution with $d f=1$, but adjusted $P$ values used the Bonferroni method because there were more comparisons than there were trees in each assay. This adjustment was also applied to the regression results of female pupal weight vs. leaf traits because they met the same condition. The dry weights of male and female pupae were log transformed and compared with one-way ANOVA.

Analyses of Foliage The concentration [given as milligrams tridecane (i.e., the internal-standard)] equivalents per gram of leaf dry mass (DM) of $\alpha$-pinene, limonene, 1,8-cineole, $\gamma$-terpinene, and $\alpha$-terpineol in fresh leaves from two representative trees of each family in GES2 and GES1 were measured according to Steinbauer et al. (2004). The extraction procedure entails immersion of $100 \mathrm{mg}$ of fresh leaf slivers in $400 \mu \mathrm{l}$ of high-performance liquid chromatography grade hexane (containing $100 \mathrm{ppm}$ tridecane as an internal standard) in sealed glass tubes followed by heating to $100^{\circ} \mathrm{C}$ for $1 \mathrm{~h}$. One microliter volume of the solvent extract was subjected to gas chromatography/mass spectrometry analysis, and quantities of each monoterpene were calculated based on reference to the response factor for the internal standard.

FÖ and MJS independently examined the same eight branchlets (each with six leaves) of each of the four $E$. nitens and ranked them on abundance of epicuticular waxes. The two sets of rankings were the same, i.e., $E$. nitens N66, N65, N64, to N63, with N66 the waxiest and N63 the least waxy.

Freeze-dried leaves were used in chemical analyses of nitrogen and sideroxylonal (an FPC), respectively. Leaves were ground in a Tecator Cyclotec 1093 mill to pass through a $1-\mathrm{mm}$ sieve, and nitrogen content was measured by using $0.35 \mathrm{~g}$ of leaf powder and a semi-micro Kjeldahl technique with a Tecator 2012 digester, selenium catalyst (3.5 g of $\mathrm{K}_{2} \mathrm{SO}_{4}, 3.5 \mathrm{mg} \mathrm{Se}$ ) and a Gerhardt Vapodest-5 distillation and titration apparatus. The method was standardized by using ammonium sulfate. The sideroxylonal content of ten individual leaves of each host used in the laboratory investigations was measured following Wallis et al. (2003). However, to ensure the extraction of all the sideroxylonal, the leaves were finely chopped, sonicated in solvent, and then extracted in solvent for 8 rather than $5 \mathrm{~h}$. 
Specific leaf weight (SLW) was measured as an indicator of leaf toughness because leaf toughness is the only foliar trait known to link oviposition preference and neonate performance in M. privata (Steinbauer 2002; Steinbauer and Matsuki 2004). Foliar water content is inversely correlated with SLW (as is nitrogen; Steinbauer and Matsuki 2004) and can be measured coincident with SLW. Consequently, it was also measured (as a percentage of leaf mass) and arcsine transformed for use in statistical tests.

The physical and chemical characteristics of the trees were also characterized to help differentiate them from one another. Global nonmetric multidimensional scaling (GNMDS), an ordination procedure, using PC-ORD was used to compare the traits of the trees. The settings used for the analyses were 40 runs with real data, 100 runs with randomized data, 500 maximum iterations, 5 (for GES2 and GES1 data; i.e., 5 monoterpenes) or 9 (for laboratory data; i.e., 5 monoterpenes, sideroxylonal $\mathrm{A}$ and $\mathrm{C}$, toughness and water content) starting dimensions, and $<0.001$ minimum instability threshold. The results of these analyses are provided as Supplementary Material.

\section{Results}

Field Investigations of Oviposition Preferences for Novel and Natural Hosts In GES2, there was no significant difference in the mean numbers of eggs on the families of E. globulus and E. rubida. There were, however, different

Table 3 Results of statistical analyses of oviposition in field and laboratory investigations

\begin{tabular}{|c|c|c|c|c|}
\hline Source or Comparison & $\begin{array}{l}d f \text { and/or Significance- } \\
\text { level and Tail }\end{array}$ & $\mathrm{SS}$ or Critical $t$ value & $F$ or $t$ Value & $P$ Value \\
\hline \multicolumn{5}{|c|}{ Field investigations GES2 (GLM) } \\
\hline Clutches & 1 & 3316.02 & 256.72 & $<0.001$ \\
\hline Species & 1 & 111.28 & 8.61 & 0.004 \\
\hline Family (species) & 2 & 10.31 & 5.15 & 0.671 \\
\hline Error & 259 & 3345.43 & 12.92 & \\
\hline Total & 263 & & & \\
\hline \multicolumn{5}{|c|}{ GES2 (post hoc one-way ANOVA) } \\
\hline Clutches by family & 3,260 & 24.60 & 3.89 & 0.010 \\
\hline Eggs by species & 1,262 & 22.70 & 0.87 & 0.351 \\
\hline Eggs by family & 3,260 & 162.10 & 2.11 & 0.099 \\
\hline \multicolumn{5}{|c|}{ Field investigations GES1 (GLM) } \\
\hline Clutches & 1 & 770.63 & 61.92 & $<0.001$ \\
\hline Family & 4 & 125.46 & 2.52 & 0.044 \\
\hline Error & 135 & 1680.04 & & \\
\hline Total & 140 & & & \\
\hline \multicolumn{5}{|c|}{ GES1 (post hoc one-way ANOVA) } \\
\hline Clutches by family & 4,136 & 3.44 & 1.93 & 0.109 \\
\hline Eggs by family & 4,136 & 319.30 & 4.43 & 0.002 \\
\hline \multicolumn{5}{|c|}{ Laboratory investigations, binary choice assays (paired-sample $t$ tests) } \\
\hline N66 cf. G76 (3-4 f) & $0.05(1), 8$ & 1.86 & 2.45 & 0.020 \\
\hline N64 cf. N66 (3-4 f) & $0.05(2), 6$ & 2.45 & 8.49 & $<0.001$ \\
\hline Mac cf. N64 (3-4 f) & $0.05(1), 4$ & 2.13 & 0.71 & 0.259 \\
\hline Cor cf. N64 (3-4 f) & $0.05(1), 4$ & 2.13 & 4.23 & 0.007 \\
\hline N64 cf. N66 (1 f) & $0.05(2), 9$ & 2.09 & 3.38 & 0.008 \\
\hline \multicolumn{5}{|c|}{ Laboratory investigations, multiple choice assays (GLM) } \\
\hline Family & 3 & 62.62 & 3.40 & 0.028 \\
\hline Female & 12 & 218.44 & 2.96 & 0.006 \\
\hline Error & 36 & 221.19 & & \\
\hline Total & 51 & & & \\
\hline \multicolumn{5}{|c|}{ Laboratory investigations, multiple choice assays (post hoc one-way ANOVA) } \\
\hline Eggs by family & 3,48 & 62.62 & 2.28 & 0.091 \\
\hline Eggs by female & 12,39 & 218.44 & 2.50 & 0.015 \\
\hline
\end{tabular}




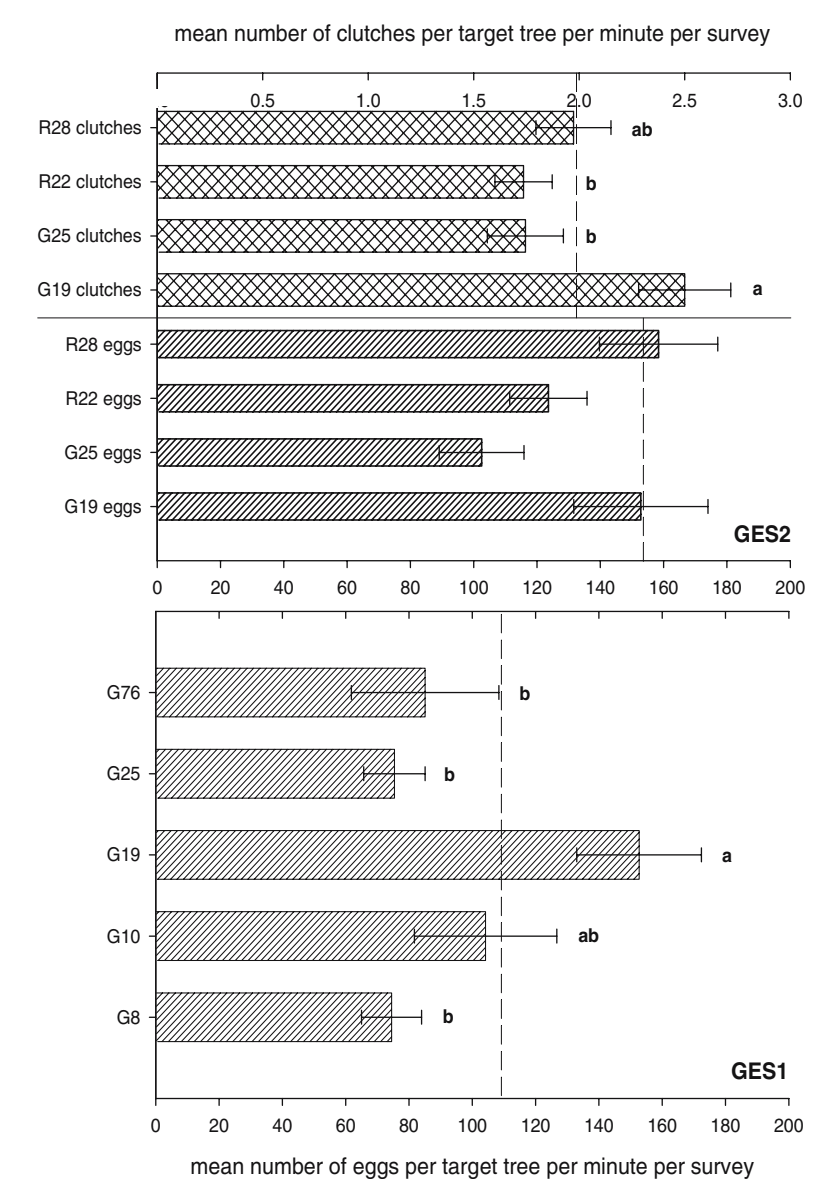

Fig. 2 Field observations of oviposition by M. privata on novel and natural hosts. (GES2) oviposition (mean number of clutches as well as mean number of eggs) on two families of E. globulus (G19 and G25) and two families of E. rubida (R28 and R22). GES1 oviposition on five families of E. globulus (G8, G10, G19, G25, and G76). Data are means $\pm \mathrm{SE}$ Dashed vertical lines indicate mean overall oviposition. Letters alongside bars indicate statistical similarity of means

numbers of clutches laid on the different families of $E$. globulus and E. rubida (Table 3, Fig. 2). Specifically, $M$. privata laid most clutches on E. globulus family G19 with only slightly fewer clutches on E. rubida family R28. Female moths laid almost identical numbers of clutches on E. globulus family G25 and E. rubida family R22, but the numbers did not differ significantly from the number laid on E. rubida family R28.

In GES1, the family of tree as well as the number of clutches significantly influenced the number of eggs on individual E. globulus (Table 3). Of the five families of primary hosts, M. privata preferred to lay on E. globulus family G19, followed by family G10 with equal preference for the remaining three families (Fig. 2).

There were two statistically significant relationships between oviposition on the nine genotypes of tree in both arboreta and the concentrations of monoterpenes in their leaves. Oviposition was negatively related to the concentration of $\alpha$-pinene but positively related to the concentration of $\alpha$-terpineol (Fig. 3). Appendix 1 shows the monoterpene concentrations. An ordination of the genotypes from both arboreta is provided in Supplementary Material, Fig. 1.

Laboratory Investigations of Oviposition Preferences for Novel and Natural Hosts Despite the leaves of E. nitens N66 being equally waxy on both surfaces, whereas those of E. globulus are most waxy on the abaxial surface, $M$. privata preferred laying on branchlets of E. globulus than on branchlets of E. nitens N66 (Table 3, Fig. 4a). The moths preferred ovipositing on leaves of the waxiest $E$.
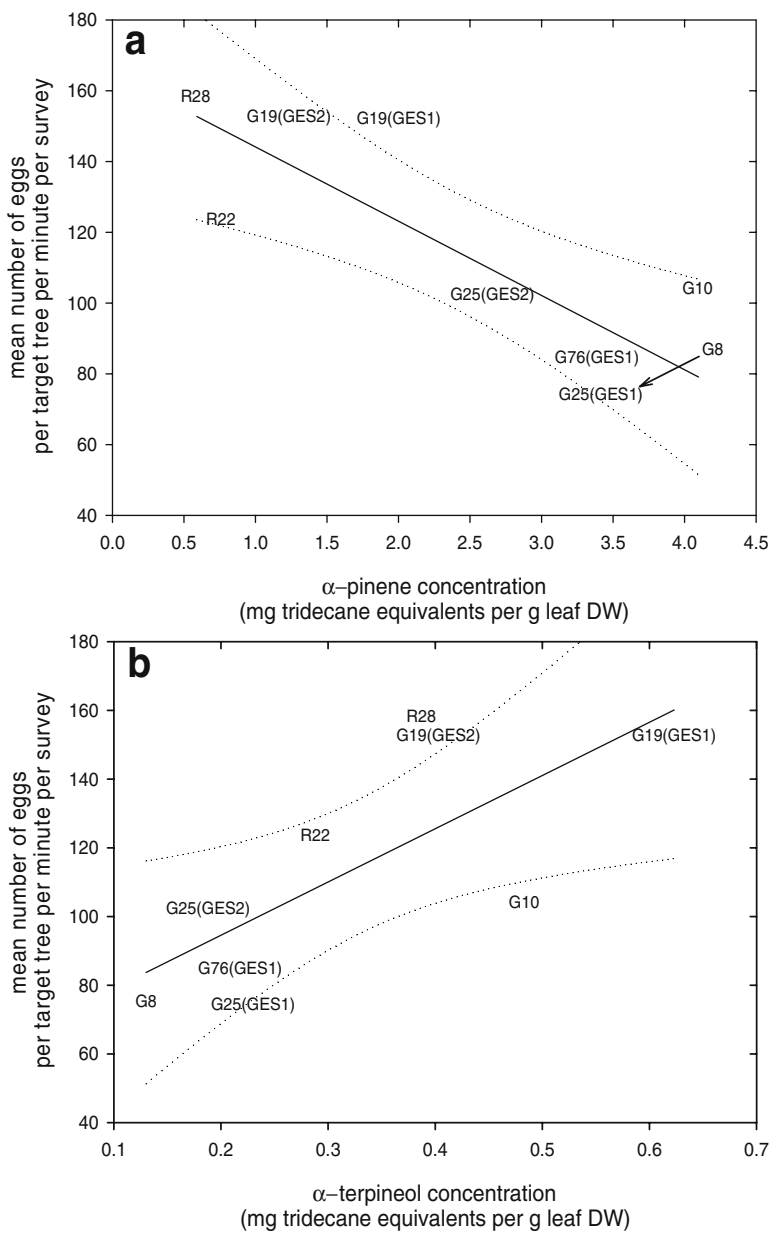

Fig. 3 Oviposition on families of E. globulus and E. rubida growing in GES2 and GES1 relative to monoterpene content. a Oviposition in relation to the concentration of $\alpha$-pinene (location of G8 offset for clarity; number of eggs $=-20.987 \times \alpha$-pinene concentration +165.092 ; $r^{2}=66.8 \%, F_{1,7}=14.109, P=0.007 ; \mathrm{SE}$ slope $=5.6, P=0.007 ; \mathrm{SE}$ intercept $=15.2, P=0.001)$. b Oviposition in relation to the concentration of $\alpha$-terpineol (number of eggs $=154.984 \times \alpha$-terpineol concentration $+63.560 ; r^{2}=52.9 \%, F_{1,7}=7.866, P=0.026$; $\mathrm{SE}$ slope $=55.3, P=$ 0.026; SE intercept $=19.9, P=0.015$ ) 

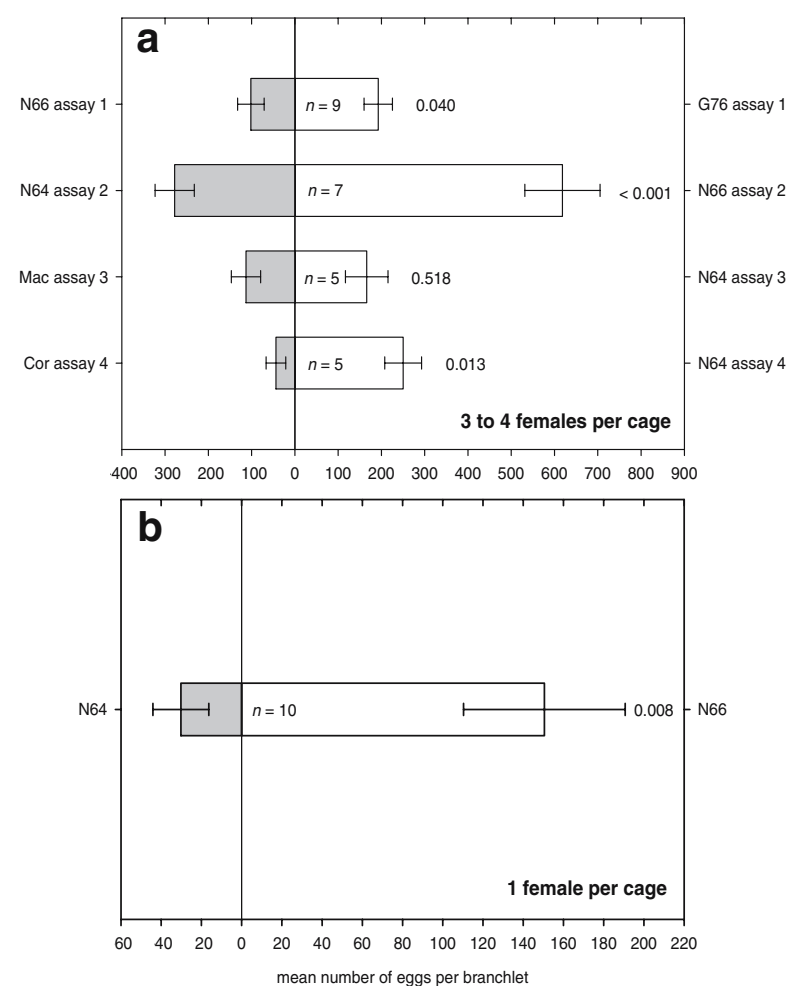

Fig. 4 Results of binary choice assays. a Oviposition by groups of three to four females per cage on branchlets of E. nitens N66 or E. globulus G76, E. nitens N64 or E. nitens N66, E. macarthurii (Mac) or E. nitens N64, and C. eximia (Cor) or E. nitens N64. b Oviposition by individual females on branchlets of $E$. nitens $\mathrm{N} 64$ or E. nitens N66. Data are means \pm SE. Two-tail probabilities, from paired-sample $t$-tests, given at RHS of bars

nitens, namely N66, to the third waxiest leaves, E. nitens N64. There was no difference in oviposition rates on the leaves of E. macarthurii, which possess structural waxes, compared to those of $E$. nitens N64 that produce nonstructural waxes. Least preferred were the leaves of $C$. eximia. Assays with 11 individual female moths offered E. nitens N64 and N66 tended to confirm the preferences obtained with groups of females. Ten females laid more eggs on leaves of $E$. nitens N66 than on leaves of N64 $(P=0.008$; Fig. 4b), but the other female laid 337 eggs on E. nitens N64 and only 51 eggs on N66 and reduced the probability of the preference response to $P=0.061$.

When individual M. privata were given a choice of four $E$. nitens on which to lay, they tended to choose them from most (N66) to least waxy (N63 then N64) $(P=0.028$; Fig. 5). Not surprisingly, the post hoc ANOVA indicated there were significant differences in the fecundities of the 13 females used in these assays.

Laboratory Investigations of Larval Survival and Performance on Novel and Natural Hosts All larvae reared on C. eximia died before completing the second instar (Fig. 6a). Not surprisingly, the survival curves for larvae on $C$. eximia differed significantly from those chosen for comparison (E. globulus, E. nitens N66, and E. macarthurii). Survival curves for these latter three did not differ (Table 4). Interestingly, larval survival was high and time to pupation short on E. macarthurii, although its leaves had the highest concentration of sideroxylonal (Fig. 6a and Appendix 1). In contrast, the leaves of $C$. eximia were devoid of sideroxylonal. The leaves of $C$. eximia, however, were the toughest of those in this set of assays, i.e., mean SLW of $0.124 \mathrm{mg}$ per $\mathrm{mm}^{2}$ compared to 0.079 , 0.082 , and $0.104 \mathrm{mg}$ per $\mathrm{mm}^{2}$ for the leaves of E. nitens N66, E. globulus, and E. macarthurii, respectively (Appendix 2).

Larvae survived significantly better on the leaves of $E$. nitens N66 and N63 than on those of N65 (Fig. $6 \mathrm{~b}$ and
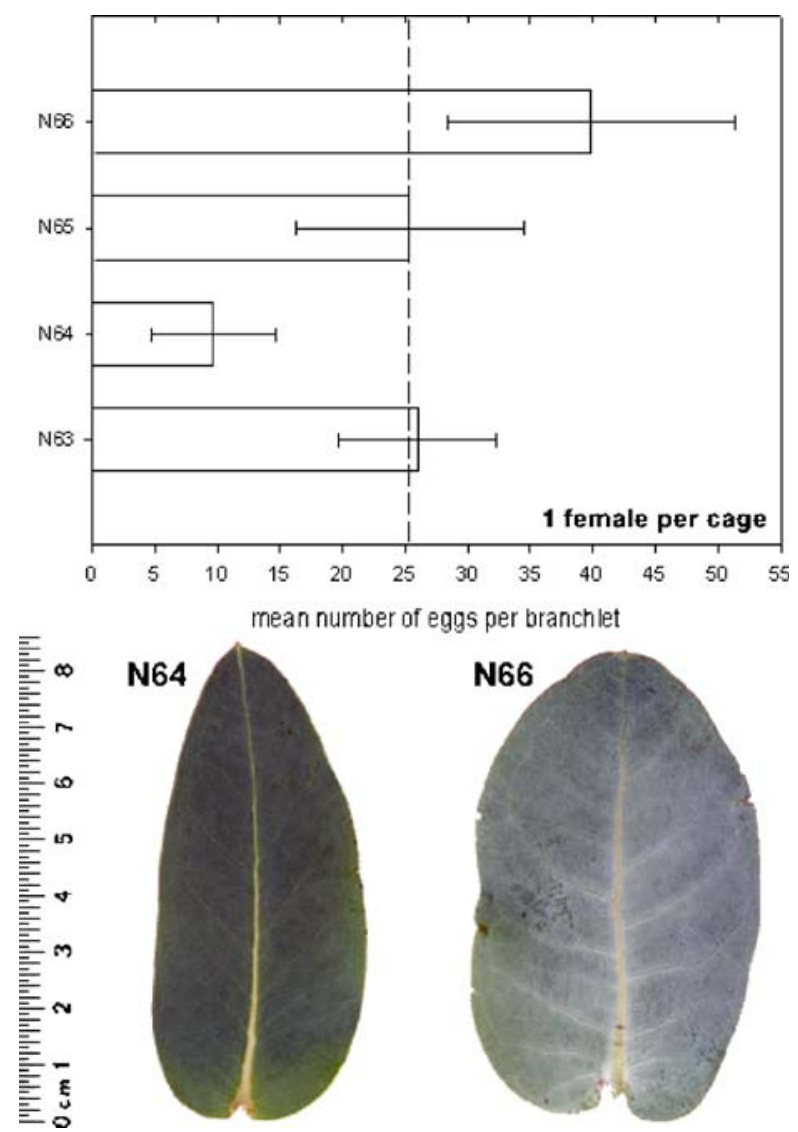

Fig. 5 Results of multiple choice assays with four E. nitens. Data are means \pm SE. Dashed vertical line indicates mean overall oviposition. The bottom two images are of the leaves of E. nitens N64 (least preferred) and of E. nitens N66 (most preferred) illustrating the relative abundance of epicuticular waxes. Epicuticular waxes are evenly distributed on both sides of juvenile E. nitens leaves 
Fig. 6 Survival of larvae on novel and natural species of Eucalyptus and Corymbia. a Survival on leaves of E. globulus G76, E. nitens N66, E. macarthurii (Mac), and C. eximia (Cor). b Survival on leaves of $E$. nitens $\mathrm{N} 63$, N64, N65, and N66. Larval survival is shown relative to the total sideroxyloday 11 (indicated by dashed vertical line) encompasses larval development to end of the second instar nal content of leaves. Period to
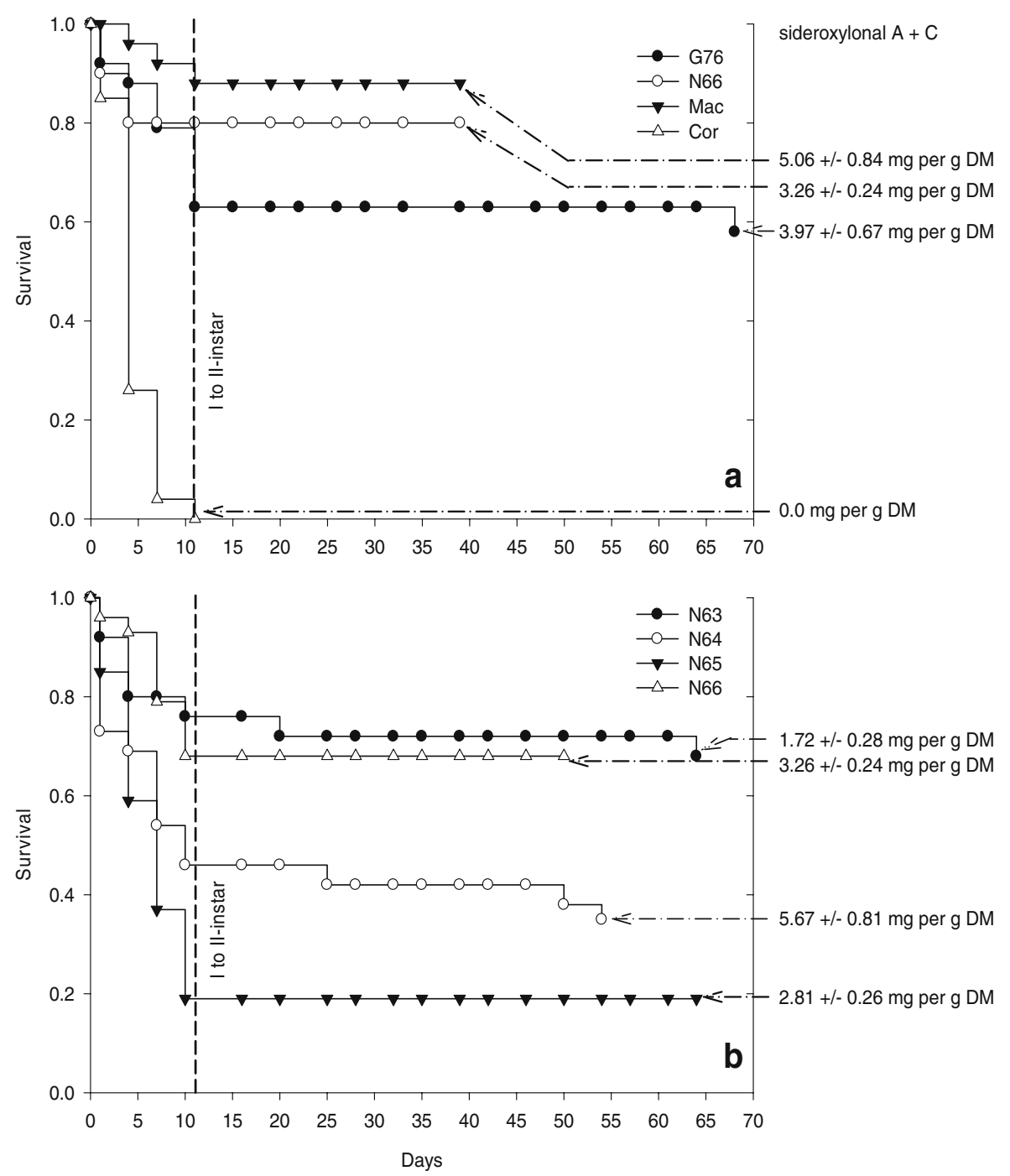

Table 4). As in the case of $C$. eximia, the higher mortality on leaves of E. nitens N65 was likely due in part to leaf toughness (Appendix 2). It is interesting to note that final larval survival on E. nitens N66 and N63 (both 0.68) as well as N64 (0.35) roughly matched the total sideroxylonal contents of the leaves of those trees (see Fig. 6b).

The dry weights of male pupae were less variable than those of female pupae (Fig. 7). With the exception of individuals fed $E$. nitens N63, male pupae tended to weigh the same irrespective of their larval diet (Table 4). In contrast, the weight of female pupae was less predictable. For example, there was little variation in the weight of female pupae reared on E. globulus, E. macarthurii, and E. nitens N66 in the first set of assays. There was, however, more variation in the weight of pupae reared on the four $E$. nitens. In particular, pupae reared on E. nitens N66 were significantly heavier than pupae reared on the leaves of $E$. nitens N64, whereas those fed E. nitens N63 were of intermediate weight. Thus, the results for larval performance exhibit a linkage to female oviposition preferences on these four E. nitens.

After a Bonferroni adjustment, there was only a single significant relationship $(P \leq 0.003)$ between female pupal weight and one of the eight leaf traits measured. Female pupal weight was negatively related to the toughness of the leaves used to rear larvae (pupal weight $=-1069.5 \times$ leaf toughness $+354.6 ; r^{2}=95.1 \%, F_{1}, 6=76.9, P<0.001 ; \mathrm{SE}$ slope $=122.0, P<0.001 ; \mathrm{SE}$ intercept $=14.8, P<0.001)$. There was a trend toward a positive relationship between the weight of female pupae and foliar nitrogen $(P=0.010)$. Leaf toughness and nitrogen were negatively related to one another (nitrogen content $=-101.5 \times$ leaf toughness +25.7 ; 
Table 4 Results of statistical analyses of larval survival and performance

\begin{tabular}{llll}
\hline Comparison or Source & $\theta$ or $d f$ & $\begin{array}{l}\text { Variance Associated } \\
\text { with } \theta \text { or SS }\end{array}$ & $\begin{array}{l}\text { Log-rank Statistic } \\
\text { or } F \text { Value }\end{array}$ \\
\hline Larval survival on G76, N66, Mac and Cor (log-rank tests) & & \\
G76 cf. N66 & 1.6 & 3.26 & 0.80 \\
G76 cf. Mac & -3.5 & 2.85 & 4.41 \\
G76 cf. Cor & 12.9 & 5.35 & 31.05 \\
N66 cf. Mac & -1.5 & 1.93 & 1.21 \\
N66 cf. Cor & 12.1 & 5.11 & 28.44 \\
Mac cf. Cor & 15.4 & 4.84 & 48.77 \\
Larval survival on N63, N64, N65 and N66 (log-rank tests) & & 6.371 \\
N63 cf. N64 & -5.9 & 5.35 & 6.62 \\
N63 cf. N65 & -9.0 & 5.89 & 13.78 \\
N63 cf. N66 & -0.4 & 3.74 & 0.04 \\
N64 cf. N65 & -3.5 & 7.58 & 1.57 \\
N64 cf. N66 & 6.0 & 5.57 & 6.47 \\
N65 cf. N66 & 9.6 & 6.03 & 15.14 \\
Larval performance on G76, N63, N64, N66 and Mac (one-way ANOVA; N65 not included, only two pupae of each gender; no larvae pupated on Cor) & 4.25 \\
male pupal weight by species and family & 4,38 & 0.06 & $<.001$ \\
female pupal weight by species and family & 4,50 & 0.13 & 7.33 \\
\hline
\end{tabular}

${ }^{a}$ Bonferroni adjustment requires $P \leq 0.004$ for statistical significance.

$r^{2}=73.7 \%, \quad F_{1,6}=11.23, P=0.029 ;$ SE slope $=30.3, P=$ 0.029; SE intercept $=3.7, P=0.002$ ).

\section{Discussion}

There were three main findings of this study. First, the laboratory assays confirmed the long-held assumption that the juvenile leaves of E. globulus are the primary host of $M$. privata. Second, the field observations and laboratory assays showed that female $M$. privata base their oviposition decisions on both nonstructural epicuticular wax and foliar monoterpene cues. Thus, they are as likely to lay their eggs on novel hosts as on a known host if the foliar chemistry resembles that of the primary host. Finally, tough leaves and high concentrations of PSMs decrease larval survival, with the fitness of female survivors apparently more likely to be adversely affected by natal host than male fitness. Importantly, these conclusions were reached by studying female oviposition preference and larval performance simultaneously and by using closely related species and families of eucalypts and a less closely related taxon within Myrtaceae, namely $C$. eximia.

By studying the oviposition preferences of $M$. privata for two members of the series Viminales (E. macarthurii with structural waxes and $E$. nitens with nonstructural waxes), our assays are the first to show that wax structural type can influence insect host assessment and oviposition. For some unknown reason, female $M$. privata preferred to lay more eggs on the least waxy family of $E$. nitens than on $E$. macarthurii that is characterized by structural waxes. The identity of the waxes that influence female oviposition remains unknown. However, because the chemical composition of a species' epicuticular waxes, as well as their method of crystallization, determines the physical structure of its wax layer, we can narrow the potential suite of biologically active wax compounds (Hallam and Chambers 1970; Carr et al. 1985). Specifically, Hallam and Chambers (1970) suggested that the presence or absence of $\beta$ diketones determined whether a eucalypt had tube or platelet type waxes, the presence of $\beta$-diketones being associated with the formation of tubes (nonstructural waxes) and the absence of $\beta$-diketones with the formation of platelets (structural waxes). Jones et al. (2002) and Rapley et al. (2004) found that reduced defoliation of certain families of E. globulus was correlated with high concentrations of benzyl $n$-tetracosanoate in the epicuticular waxes of those trees and suggested that this wax ester was an oviposition repellent. Steinbauer et al. (2004) argued that the epicuticular waxes of eucalypts were likely to be oviposition stimulants. Because, according to Hallam and Chambers (1970), wax esters are associated with both tube and platelet waxes, benzyl $n$-tetracosanoate seems even less likely to be the biologically active component responsible 

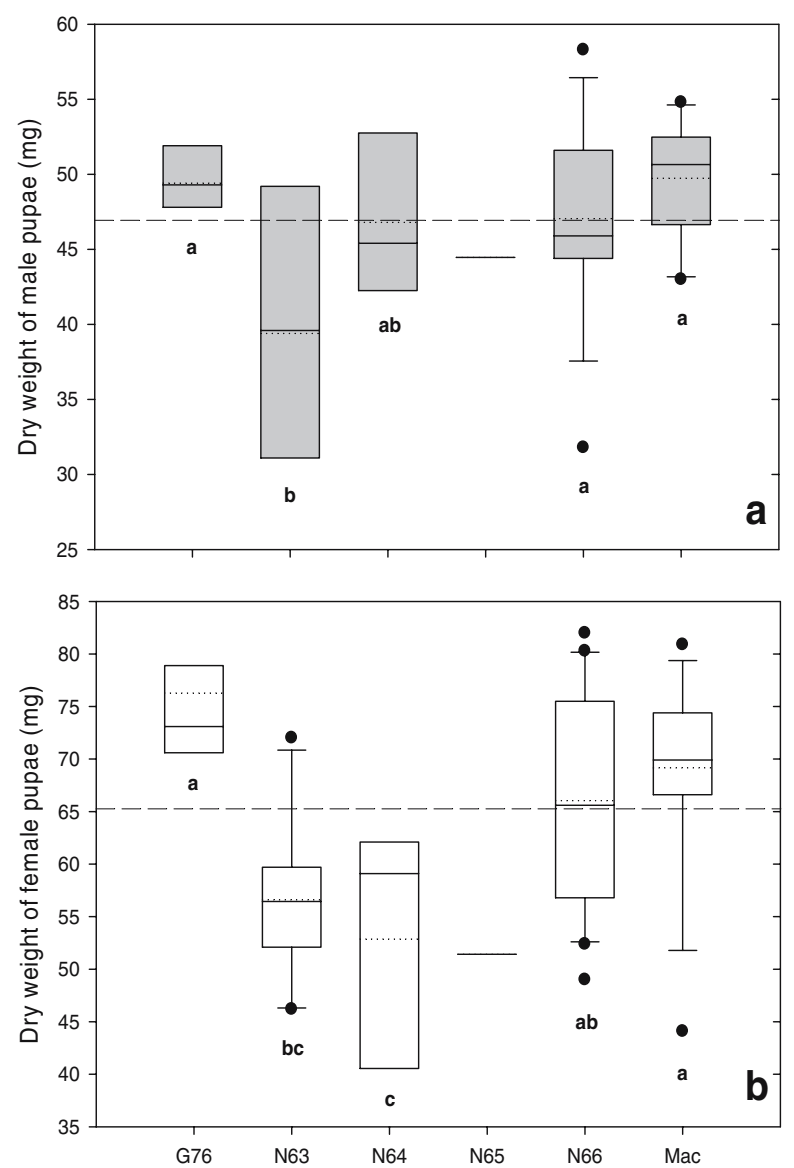

Fig. 7 Dry weights of pupae reared during survival assays. a Male pupae. b Female pupae. No larvae survived to pupation on $C$. eximia. Figures are box plots with standard error bars (if $N \geq 10$ ); the boundary of the box nearest the $x$-axis represents the 25th percentile, the solid line within the box marks the median, the dotted line within the box marks the mean, the boundary of the box furthest from the x-axis represents the 75th percentile and solid circles are outlying pupae. The dashed horizontal lines extending across each individual figure mark mean overall pupal weight. Letters beneath boxes indicate statistical similarity of means. Two male and two female pupae only were reared on $E$. nitens $\mathrm{N} 65$

for the repellence of oviposition by female M. privata. Final elucidation of the biological activity of particular wax compounds will require "boutique" synthesis and assay in choice experiments, perhaps with supplementary electrophysiological studies.

The possibility that host attractiveness for oviposition may be influenced by the concentrations of $\alpha$-pinene and $\alpha$-terpineol is of interest because there is apparently only one other parallel in insect-Myrtaceae relationships. Specifically, Wheeler and Ordung (2005) reported that the psyllid Boreioglycaspis melaleuca (Hemiptera: Psyllidae) laid more than twice as many eggs on a viridiflorol chemotype of its host (Melaleuca quinquenervia) than it did on a $E$-nerolidol chemotype. The families of E. globulus and E. rubida in GES2 and GES1 were best differentiated by their concentrations of 1,8-cineole $(100 \%)$, followed by $\alpha$-pinene $(98.0 \%)$, and least differentiated by $\gamma$-terpinene $(38.0 \%$; see GNMDS analysis in Supplementary Material, Fig. 1). The leaves of $E$. globulus had two to three times more 1,8-cineole than did those of E. rubida, but M. privata laid a similar number of eggs on each species or family. Therefore, if female $M$. privata prefer hosts with high concentrations of 1,8-cineole, they should not choose E. rubida when there are ample E. globulus nearby. Our results, however, suggest that $M$. privata do not discriminate hosts so simply. In exploratory analyses not presented here, there was a negative relationship $\left(r^{2}=94.6 \%\right)$ between oviposition and the ratio of the concentrations of $\alpha$-pinene to 1,8 cineole. There was, however, a close positive correlation between the concentrations of $\alpha$-pinene and 1,8-cineole $\left(r^{2}=65.4 \%\right)$, which illustrates how difficult it is to separate the influences on oviposition of individual monoterpenes. Finally, terpenes that occur in lower concentrations than 1,8-cineole or $\alpha$-pinene should not be ignored because the antennae of female moths responded to several of these aromatics, e.g., terpinolene, $\alpha$-campholene aldehyde, $\alpha$-terpineol, and possibly also trans-pinocarveol (see Steinbauer et al. 2004).

Exaptation of $M$. privata larvae enables them to eat the leaves of more species of eucalypt (notably those with glossy leaves) than females would choose to oviposit upon. Irrespective of this, high leaf toughness is universally detrimental to neonates because their small size and gape constrains the physical forces they can exert on leaf surfaces. Steinbauer and Matsuki (2004) reported that small groups of neonate M. privata larvae (e.g., $\leq 5$ larvae) were unable to create a feeding scar when leaf toughness exceeded $0.20 \mathrm{mg}$ per $\mathrm{mm}^{2}$. High leaf toughness may partly explain the deaths of all the larvae on $C$. eximia before the completion of the second instar. However, there were probably additional reasons for the demise of the larvae fed Corymbia, although sideroxylonal could not have been among them because the species is devoid of this compound. For example, C. eximia differed notably from others used in the laboratory investigations by its high concentrations of $\alpha$-pinene and $\gamma$-terpinene (Supplementary Material, Fig. 2). Exactly how sideroxylonal might be detrimental to neonate $M$. privata is a mystery. Research by Moore and Evertz (2006, unpubl.) has shown that sideroxylonal is most likely synthesized by the cells surrounding the oil glands and may be stored within the oil glands. However, neonate and second instars typically 
feed on young, expanding leaves and, even then, around oil glands (Steinbauer and Matsuki 2004). Because oil glands are not fully formed until leaf expansion is complete (Carr and Carr 1970), it seems probable that young larvae ingest sideroxylonal by rupturing or swallowing oil gland progenitor cells. Oil gland progenitor cells synthesize sideroxylonal and monoterpenes before the maturation of the oil glands and are densely packed in expanding leaves (Moore, pers. comm.). When larvae are large enough to ingest whole leaf fragments (i.e., from the third instar onward), they are exposed to the sideroxylonal in the leaves of their hosts because they disrupt and swallow mature oil glands.

The lower larval survival on hosts that produce both sideroxylonal and modest to high concentrations of monoterpenes vs. the higher survival of larvae on a host that produces high concentrations of sideroxylonal but virtually no monoterpenes (namely E. macarthurii) could suggest that variations in sideroxylonal concentration alone do not determine survival. [According to Boland et al. (1991), E. macarthurii has a total oil content between 0.8 and $1.1 \%$ (fresh weight), but its main component is geranyl acetate, followed by $\beta-, \alpha-$, and $\gamma$-eudesmol, respectively]. The severity of defoliation by adult Christmas beetles of trees of six species of eucalypt was negatively correlated with the concentration of 1,8-cineole in leaves (Edwards et al. 1993). Edwards et al. (1993) did not attribute this reduction in feeding solely to cineole. It has subsequently been shown in folivorous marsupials of eucalypts only (although a similar interaction is considered likely to occur in insects also) that high cineole odors act as a cue for the presence of high concentrations of sideroxylonal, which is actually the compound that the animals appear to avoid (Lawler et al. 2000). McLean et al. (2004) have shown that the biological activity of jensenone and sideroxylonal arises because the functional aldehyde groups of both compounds bind with the natural amines on the animal's gut wall (again, a similar mechanism is thought likely to also occur in insect herbivores). Hence, there is some evidence for interactive effects between monoterpenes and FPCs-albeit preingestion. Because a number of species of insects metabolize certain foliar monoterpenes (Ohmart and Larsson 1989; Fletcher et al. 2000; Schmidt et al. 2000; Southwell et al. 1995, 2003), perhaps, the addition of high concentrations of sideroxylonal to the ingesta overwhelms the capacity of the insect gut to degrade all the compounds, and it is via this mode of action that sideroxylonal affects larval survival. If high oil content alone antagonized the toxicity of moderate concentrations of sideroxylonal, such an interaction should have been noted sooner than now because the relationship would hold across different Eucalyptus species that synthesize it. Because E. nitens N64 (the family least preferred by female and least suitable for larvae) can be only partially differentiated from trees of the three other families of $E$. nitens by its concentrations of $\alpha$-terpineol, 1,8-cineole, and limonene (Supplementary Material, Fig. 3), perhaps attention should be given to the interactions of these monoterpenes and sideroxylonal.

The phenomenon surrounding the occurrence of outbreaks of M. privata in mixed plantations of E. globulus and other eucalypts may be a consequence of the insect experiencing a variety of primary host and other eucalypt monoterpene odors. Liu et al. (2005) reported that Plutella xylostella (Lepidoptera: Plutellidae) could be attracted to non-host volatiles on a preferred host plant if they had previously experienced the odor. By this scenario, $M$. privata that develop on E. globulus might acquire an induced preference for the neighboring species of eucalypt, thus increasing the chance that they might later oviposit on them. The results of Linn et al. (2005) that showed that most Rhagoletis pomonella (Diptera: Tephritidae) fly toward the odor of their developmental host suggest that such a change would happen slowly. Likewise, the similarity of the natal host and the non-host is likely to influence the extent to which slight alterations of preference result in expansion onto the novel species (Bengtsson et al. 2006). Perhaps, given this background, outbreaks of $M$. privata in single species plantations of novel species of eucalypt are as yet unknown.

We suggest that our findings demonstrate how similarities between novel and preferred eucalypt species, both in terms of their epicuticular wax and monoterpene compositions, may have facilitated the host expansions by $M$. privata that have been observed in the past couple of decades. From an applied perspective, an important question to address would be whether host races of $M$. privata now exist. Future studies should examine whether females prefer to oviposit on the species on which they develop and whether they prefer to mate with males that have developed on that same host. It would also be important to know whether the limits to the detoxification capacity of larvae have prevented the occurrence of a greater number of host expansion events than have already been witnessed.

Acknowledgments We thank Nick Collett, John Connors, David de Little, Jane Elek, Kirsten Evertz, William "Bill” Foley, Anne Hastings, Ken Hill, Ben Moore, Jan Scheirs, and Rex Sutherland for their assistance/advice. Colleagues Caroline Müller, Helen Nahrung, and Sören Nylin provided useful comments on an early draft of the manuscript. This study was conducted while FÖ was a visiting Postdoctoral Fellow supported by funding from the Hellmuth Hertz Foundation and CF Lundströms Stiftelse. 


\section{Appendix 1}

Table 5 Results of foliar chemical analyses

\begin{tabular}{|c|c|c|c|c|c|c|c|c|}
\hline Family & $\alpha$-Pinene & Limonene & 1,8-Cineole & $\gamma$-Terpinene & $\alpha$-Terpineol & $\begin{array}{l}\text { Sideroxylonal } \\
\text { A }\end{array}$ & $\begin{array}{l}\text { Sideroxylonal } \\
\text { C }\end{array}$ & Nitrogen \\
\hline \multicolumn{9}{|c|}{ Field investigations GES $2 n=4$ leaves (SE are per tree estimates [leaves from two trees per family]) } \\
\hline $\mathrm{R} 28$ & $0.60^{\mathrm{b}} \pm 0.033$ & $0.92^{\mathrm{a}} \pm 0.163$ & $5.92^{\mathrm{ab}} \pm 0.029$ & 0 & $0.39 \pm 0.004$ & & & \\
\hline $\mathrm{R} 22$ & $0.76^{\mathrm{b}} \pm 0.055$ & $1.66^{\mathrm{a}} \pm 0.299$ & $4.88^{\mathrm{b}} \pm 0.794$ & $0.007 \pm 0.010$ & $0.29 \pm 0.033$ & & & \\
\hline G25 & $2.66^{\mathrm{a}} \pm 0.322$ & $0.01^{\mathrm{b}} \pm 0.004$ & $12.02^{\mathrm{ab}} \pm 4.571$ & $0.005 \pm 0.007$ & $0.19 \pm 0.180$ & & & \\
\hline G19 & $1.23^{\mathrm{b}} \pm 0.025$ & $0.05^{\mathrm{b}} \pm 0.004$ & $14.50^{\mathrm{a}} \pm 1.294$ & $0.88 \pm 0.127$ & $0.40 \pm 0.088$ & & & \\
\hline \multicolumn{9}{|c|}{ Field investigations GES1 $n=4$ leaves (SE are per tree estimates [leaves from two trees per family]) } \\
\hline G76 & $3.38 \pm 0.831$ & $0.05 \pm 0.025$ & $12.22^{\mathrm{b}} \pm 1.025$ & $0.04 \pm 0.021$ & $0.22^{\mathrm{b}} \pm 0.067$ & & & \\
\hline G25 & $3.42 \pm 1.128$ & $0.02 \pm 0.007$ & $12.21^{\mathrm{b}} \pm 0.286$ & 0 & $0.23^{\mathrm{b}} \pm 0.007$ & & & \\
\hline G19 & $2.00 \pm 0.124$ & $0.04 \pm 0.004$ & $18.43^{\mathrm{ab}} \pm 0.877$ & $0.07 \pm 0.064$ & $0.62^{\mathrm{a}} \pm 0.088$ & & & \\
\hline G10 & $4.10 \pm 0.103$ & $0.27 \pm 0.343$ & $19.68^{\mathrm{a}} \pm 1.439$ & 0 & $0.48^{\mathrm{a}} \pm 0.060$ & & & \\
\hline G8 & $3.62 \pm 0.332$ & $0.03 \pm 0.000$ & $15.20^{\mathrm{ab}} \pm 0.735$ & $0.01 \pm 0.014$ & $0.13^{\mathrm{b}} \pm 0.078$ & & & \\
\hline \multicolumn{9}{|c|}{ Laboratory investigations } \\
\hline & $n=12$ leaves & & & & & $n=10$ & & $n=4$ \\
\hline G76 & $0.84 \pm 0.044^{\mathrm{b}}$ & $0.69 \pm 0.053^{\mathrm{a}}$ & $9.14 \pm 0.577^{\mathrm{a}}$ & $0.02 \pm 0.002^{\mathrm{b}}$ & $0.30 \pm 0.027^{\mathrm{a}}$ & $2.82 \pm 0.465^{\mathrm{ab}}$ & $1.15 \pm 0.203^{\mathrm{ab}}$ & $15.4 \pm 0.81^{\mathrm{a}}$ \\
\hline N63 & $0.45 \pm 0.043^{\mathrm{c}}$ & $0.06 \pm 0.007^{\mathrm{c}}$ & $1.07 \pm 0.093^{\mathrm{c}}$ & $0.01 \pm 0.002^{\mathrm{b}}$ & $0.02 \pm 0.008^{\mathrm{c}}$ & $1.19 \pm 0.204^{\mathrm{b}}$ & $0.53 \pm 0.078^{b}$ & $13.6 \pm 0.78^{\mathrm{ab}}$ \\
\hline N64 & $0.60 \pm 0.032^{b c}$ & $0.13 \pm 0.007^{\mathrm{b}}$ & $1.77 \pm 0.085^{\mathrm{b}}$ & 0 & $0.28 \pm 0.015^{\mathrm{a}}$ & $4.17 \pm 0.642^{\mathrm{a}}$ & $1.50 \pm 0.241^{\mathrm{a}}$ & $12.3 \pm 0.41^{\mathrm{b}}$ \\
\hline N65 & $0.46 \pm 0.029^{c}$ & $0.07 \pm 0.005^{\mathrm{c}}$ & $1.52 \pm 0.073^{\mathrm{bc}}$ & 0 & $0.09 \pm 0.008^{\mathrm{b}}$ & $1.98 \pm 0.185^{\mathrm{b}}$ & $0.83 \pm 0.078^{\mathrm{ab}}$ & $8.4 \pm 0.46^{\mathrm{c}}$ \\
\hline N66 & $0.74 \pm 0.050^{\text {bc }}$ & $0.10 \pm 0.005^{\mathrm{bc}}$ & $1.32 \pm 0.061^{\mathrm{c}}$ & 0 & $0.06 \pm 0.005^{\mathrm{bc}}$ & $2.29 \pm 0.167^{\mathrm{ab}}$ & $0.97 \pm 0.072^{\mathrm{ab}}$ & $15.0 \pm 0.77^{\mathrm{a}}$ \\
\hline Cor & $2.26 \pm 0.166^{\mathrm{a}}$ & $0.03 \pm 0.002^{\mathrm{c}}$ & $0.03 \pm 0.002^{\mathrm{d}}$ & $0.34 \pm 0.028^{\mathrm{a}}$ & 0 & 0 & 0 & $14.5 \pm 0.29^{\mathrm{a}}$ \\
\hline Mac & 0 & 0 & 0 & 0 & 0 & $3.72 \pm 0.617^{\mathrm{a}}$ & $1.34 \pm 0.227^{\mathrm{a}}$ & $17.0 \pm 0.89^{\mathrm{a}}$ \\
\hline
\end{tabular}

Data are Means \pm SE. Superscripted letters down columns for same investigation indicate mean difference at $P \leq 0.05$. Concentrations of monoterpenes are as milligrams tridecane equivalents per gram of leaf dry weight. All other concentrations are as actual milligrams per gram leaf dry weight.

\section{Appendix 2}

Table 6 Leaf toughnesses (in milligrams per square millimeter) and water contents (in percentages) of leaves representative of those used in laboratory investigations

\begin{tabular}{|c|c|c|c|c|}
\hline Assay & Host 1 & Host 2 & Host 3 & Host 4 \\
\hline \multicolumn{5}{|c|}{ Oviposition preference } \\
\hline Binary 1 & N66 & G76 & & \\
\hline Toughness & $0.151 \pm 0.0062^{\mathrm{a}}$ & $0.111 \pm 0.0049^{\mathrm{b}}$ & & \\
\hline Water & $45.8 \pm 0.46^{\mathrm{b}}$ & $54.9 \pm 0.54^{\mathrm{a}}$ & & \\
\hline Binary 2 & N64 & N66 & & \\
\hline Toughness & $0.147 \pm 0.0065^{\mathrm{a}}$ & $0.119 \pm 0.0042^{\mathrm{b}}$ & & \\
\hline water & $50.7 \pm 0.78$ & $49.6 \pm 0.67$ & & \\
\hline Binary 3 & Mac & N64 & & \\
\hline Toughness & $0.104 \pm 0.0037^{\mathrm{b}}$ & $0.144 \pm 0.0054^{\mathrm{a}}$ & & \\
\hline Water & $47.2 \pm 1.35$ & $47.5 \pm 0.37$ & & \\
\hline Binary 4 & Cor & N64 & & \\
\hline Toughness & $0.124 \pm 0.0034$ & $0.135 \pm 0.0050$ & & \\
\hline Water & $59.1 \pm 0.94^{\mathrm{a}}$ & $52.6 \pm 0.62^{\mathrm{b}}$ & & \\
\hline Multiple & N63 $n=20$ leaves & N64 & N65 & N66 \\
\hline Toughness & $0.125 \pm 0.0057^{\mathrm{b}}$ & $0.131 \pm 0.0027^{\mathrm{b}}$ & $0.154 \pm 0.0051^{\mathrm{a}}$ & $0.118 \pm 0.0030^{\mathrm{t}}$ \\
\hline Water & $52.4 \pm 0.75$ & $54.4 \pm 0.70$ & $46.8 \pm 0.94$ & $52.1 \pm 0.48$ \\
\hline \multicolumn{5}{|c|}{ Larval survival and performance } \\
\hline & $\operatorname{Mac}^{\dagger}$ & $\operatorname{Cor}^{\dagger}$ & N66 & G76 \\
\hline Toughness & 0.104 & 0.124 & $0.079 \pm 0.0021$ & $0.082 \pm 0.0033$ \\
\hline \multirow[t]{2}{*}{ Water } & 47.2 & 59.1 & $61.8 \pm 0.66^{\mathrm{b}}$ & $65.3 \pm 1.03^{\mathrm{a}}$ \\
\hline & N63 & N64 & N65 & N66 \\
\hline Toughness & $0.137 \pm 0.0041^{\mathrm{a}}$ & $0.132 \pm 0.0034^{\mathrm{ab}}$ & $0.150 \pm 0.0078^{\mathrm{a}}$ & $0.115 \pm 0.0045^{t}$ \\
\hline Water & $49.5 \pm 0.34^{\mathrm{a}}$ & $48.1 \pm 0.40^{\mathrm{b}}$ & $46.0 \pm 0.27^{\mathrm{c}}$ & $50.3 \pm 0.30^{\mathrm{a}}$ \\
\hline
\end{tabular}

${ }^{\dagger}$ These means are the same as those measured for leaves used in binary choice assays 3 and 4 . The leaves used in the choice assays were harvested on 31 January and 7 February, respectively, whereas the survival assay was begun on 6 March. Therefore, the toughness of the leaves of C. eximia and E. macarthurii that were used in this assay was not thought necessary to measure because they were likely to be comparable to those of leaves harvested earlier

Data are means $\pm \mathrm{SE}, N=10$ leaves unless otherwise stated. Superscripted letters along rows indicate mean difference at $P \leq 0.05$ 


\section{References}

Bengtsson, M., JaAstad, G., Knudsen, G., Kobro, S., Bäckman, A.-C., Pettersson, E., and WitzGall, P. 2006. Plant volatiles mediate attraction to host and non-host plant in apple fruit moth, Argyresthia conjugella. Entomol. Exp. Appl. 118:77-85.

Boland, D. J., BRoPhy, J. J., and House, A. P. N. 1991. Eucalyptus Leaf Oils: Use, Chemistry, Distillation and Marketing. Inkata Press, Melbourne, Australia.

Braby, M. F. and Trueman, J. W. H. 2006. Evolution of larval host plant associations and adaptive radiation in pierid butterflies. $J$. Evol. Biol. 19:1677-1690.

BROOKER, M. I. H. 2000. A new classification of the genus Eucalyptus L'Hér. (Myrtaceae). Aust. Syst. Bot. 13:79-148.

CARR, D. J. and CARR, S. G. M. 1970. Oil glands and ducts in Eucalyptus L'Hérit. II. Development and structure of oil glands in the embryo. Aust. J. Bot. 18:191-212.

CARR, D. J., CARR, S. G. M., and LENZ, J. R. 1985. Oriented arrays of epicuticular wax plates in Eucalyptus species. Protoplasma 124:205-212.

ChIPPENDAle, G. M. 1988. Flora of Australia, Volume 19. MyrtaceaeEucalyptus, Angophora. Australian Government Publishing Service, Canberra, Australia.

EdWARdS, P. B., WANJURA, W. J., and Brown, W. V. 1993. Selective herbivory by Christmas beetles in response to intraspecific variation in Eucalyptus terpenoids. Oecologia 95:551-557.

Eschler, B. M., PAss, D. M., Willis, R., and Foley, W. J. 2000. Distribution of foliar formylated phloroglucinol derivatives amongst Eucalyptus species. Biochem. Syst. Ecol. 28:813-824.

Evans, J. W. 1943. Insect Pests and Their Control. Government Printer, Hobart, Australia.

Fletcher, M. T., Lowe, L. M., Kitching, W., and Konig, W. A. 2000. Chemistry of Leichhardt's grasshopper, Petasida ephippigera, and its host plants, Pityrodia jamesii, P. ternifolia and P. pungens. J. Chem. Ecol. 26:2275-2290.

FRENCH, C. 1900. A Handbook of the Destructive Insects of Victoria, With Notes on the Methods to be Adopted to Check and Extirpate Them. Part III. Government Printer, Melbourne, Australia.

Froggatt, W. W. 1923. Forest Insects of Australia. Government Printer, Sydney, Australia.

Grosman, A. M., van Breemen, M., Holtz, A., Pallini, A., Rugama, A. M., Pengel, H., Venzon, M., Zanuncio, J. C., SABELIS, M. W., and JANSSEN, A. 2005. Searching behaviour of an omnivorous predator for novel and native host plants of its herbivores: a study on arthropod colonisation of Eucalyptus in Brazil. Entomol. Exp. Appl. 116:135-142.

Hallam, N. D. and Chambers, T. C. 1970. The leaf waxes of the genus Eucalyptus L'Héritier. Aust. J. Bot. 18:335-386.

HiLl, K. D. and Johnson, L. A. S. 1995. Systematic studies in the eucalypts 7. A revision of the bloodwoods, genus Corymbia (Myrtacaeae). Telopea 6:185-504.

Hobbs, R. J., Floyd, R. B., Cunningham, S. A., Catling, P., and IVE, J. 2003. Hardwood Plantations: Quantifying Conservation and Environmental Service Benefits. Rural Industries Research and Development Corporation, Canberra, Australia. http://www. rirdc.gov.au/reports/AFT/02-83.pdf

JANZ, N. and NYLIN, S. 1998. Butterflies and plants: a phylogenetic study. Evolution 52:486-502.

JANZ, N., NYBLOM, K., and NYLIN, S. 2001. Evolutionary dynamics of host-plant specialisation: a case study of the tribe Nymphalini. Evolution 55:783-796.

Jones, T. H., Potts, B. M., Vaillancourt R. E., and Davies, N. W. 2002. Genetic resistance of Eucalyptus globulus to autumn gum moth defoliation and the role of cuticular waxes. Can. J. For. Res. 32:1961-1969.

Ladiges, P. Y. and Udovicic, F. 2000. Comment on a new classification of the eucalypts. Aust. Syst. Bot. 13:149-152.

Ladiges, P. Y., Udovicic, F., and DrinNAN, A. N. 1995. Eucalypt phylogeny - molecules and morphology. Aust. Syst. Bot. 8:483-497.

LAWLer, I. R., Foley, W. J., and Eschler, B. M. 2000. Foliar concentrations of a single toxin creates habitat patchiness for a marsupial folivore. Ecology 81:1327-1338.

Li, H., MAdDEN, J. L., and PotTs, B. M. 1995. Variation in volatile leaf oils of the Tasmanian Eucalyptus species I. Subgenus Monocalyptus. Biochem. Syst. Ecol. 23:299-318.

LI, H., MADDEN, J. L., and POTTS, B. M. 1996. Variation in volatile leaf oils of the Tasmanian Eucalyptus species II. Subgenus Symphyomyrtus. Biochem. Syst. Ecol. 24:547-569.

Li, H., MAdDEN, J. L., and PotTS, B. M. 1997. Variation in leaf waxes of the Tasmanian Eucalyptus species I. Subgenus Symphyomyrtus. Biochem. Syst. Ecol. 25:631-657.

Linn Jr., C. E., Dambroski, H., Nojima, S., Feder, J. L., Berlocher, S. H., and Roelofs, W. L. 2005. Variability in response specificity of apple, hawthorn, and flowering dogwoodinfesting Rhagoletis flies to host fruit volatile blends: implications for sympatric host shifts. Entomol. Exp. Appl. 116:55-64.

LiU, S.-S., LI, Y.-H., LiU, Y.-Q., and ZALUCKI, M. P. 2005. Experience-induced preference for oviposition repellents derived from a non-host plant by a specialist herbivore. Ecol. Letters $8: 722-729$.

LOCH, A. D. and FloYd, R. B. 2001. Insect pests of Tasmanian blue gum, Eucalyptus globulus globulus, in south-western Australia: History, current perspectives and future prospects. Austral Ecol. 26:458-466.

Mclean, S., Brandon, S., Davies, N. W., Foley, W. J., and Muller, H. K. 2004. Jensenone: biological reactivity of a marsupial antifeedant from Eucalyptus. J. Chem. Ecol. 30:19-36.

Moore, K. M. 1972. Observations on some Australian forest insects 26. Some insects attacking three important tree species. Aust. Zool. 17:30-39.

Murphy, S. M. and FeENY, P. 2006. Chemical facilitation of a naturally occurring host shift by Papilio machaon butterflies (Papilionidae). Ecol. Mono. 76:399-414.

OHMART, C. P. and LARSSON, S. 1989. Evidence for absorption of eucalypt essential oils by Paropsis atomaria Olivier (Coleoptera: Chrysomelidae). J. Aust. Ent. Soc. 28:201-205.

RAPley, L. P., Allen, G. R., and PotTs, B. M. 2004. Susceptibility of Eucalyptus globulus to Mnesampela privata defoliation in relation to a specific foliar wax compound. Chemoecology 14:157-163.

RoBerTs, R. J. and SAWTELL, N. L. 1981. Survival and growth of local and other eucalypts planted on the Northern Tablelands, pp. 87-94, in K. M. Old, G. A. Kile, and C. P. Ohmart (eds.). Eucalypt Dieback in Forests and Woodlands. CSIRO, Melbourne, Australia.

Schmidt, S., Walter, G. H., and Moore, C. J. 2000. Host plant adaptations in myrtaceous-feeding pergid sawflies: essential oils and the morphology and behaviour of Pergagrapta larvae (Hymenoptera, Symphyta, Pergidae). Biol. J. Linn. Soc. 70:15-26.

Southwell, I. A., MadDOX, C. D. A., and ZaluCKI, M. P. 1995. Metabolism of 1,8-cineole in tea tree (Melaleuca alternifolia and M. linariifolia) by pyrgo beetle (Paropsisterna tigrina). J. Chem. Ecol. 21:439-453.

Southwell, I. A., Russell, M. F., Maddox, C. D. A., and WHEELER, G. S. 2003. Differential metabolism of 1,8-cineole in insects. J. Chem. Ecol. 29:83-94.

SteinBAuER, M. J. 2002. Oviposition preference and neonate performance of Mnesampela privata in relation to heterophylly 
in Eucalyptus dunnii and E. globulus. Agric. For. Entomol. $4: 245-253$.

Steinbauer, M. J. and Matsuki, M. 2004. Suitability of Eucalyptus and Corymbia for Mnesampela privata (Guenée) (Lepidoptera: Geometridae) larvae. Agric. For. Entomol. 6:323-332.

Steinbauer, M. J. and WANJURA, W. J. 2002. Christmas beetles (Anoplognathus spp., Coleoptera: Scarabaeidae) mistake peppercorn trees for eucalypts. J. Nat. Hist. 36:119-125.

Steinbauer, M. J., Schiestl, F. P., and Davies, N. W. 2004. Monoterpenes and epicuticular waxes help female autumn gum moth differentiate between waxy and glossy Eucalyptus and leaves of different ages. J. Chem. Ecol. 30:1117-1142.

STONE, C. and URQUHART, C. A. 1992. Effects of treating young hand planted eucalypts with selected systemic insecticides, and identification of associated foliage insects. Gen. Appl. Entomol. 24:53-63.
Udovicic, F., McFadden, G. I., and Ladiges, P. Y. 1995. Phylogeny of Eucalyptus and Angophora based on 5S rDNA spacer sequence data. Mol. Phylogen. Evol. 4:247-256.

Wallis, I. R., Herlt, A. J., Eschler, B. M., Takasaki, M., and FOLEY, W. J. 2003. Quantification of sideroxylonals in Eucalyptus foliage by high-performance liquid chromatography. Phytochem. Anal. 14:360-365.

Wardell-Johnson, G. W., Williams, J. E., Hill, K. D., and CuMming, R. 1997. Evolutionary biogeography and contemporary distribution of eucalypts, pp. $92-128$, in J. E. Williams and J. C. Woinarski (eds.). Eucalypt ecology: Individuals to Ecosystems. Cambridge University Press, Cambridge, UK.

WheEler, G. S. and OrdunG, K. M. 2005. Secondary metabolite variation affects the oviposition preference but has little effect on the performance of Boreioglycaspis melaleucae: A biological control agent of Melaleuca quinquenervia. Biol. Cont. 35:115-123. 